\title{
Altered phenotypic and functional characteristics of CD3+CD56+ NKT-like cells in human gastric cancer
}

\author{
Liu-sheng Peng ${ }^{1}$, Fang-yuan Mao ${ }^{1}$, Yong-liang Zhao ${ }^{2}$, Ting-ting Wang ${ }^{1}$, Na Chen ${ }^{1}$, \\ Jin-yu Zhang ${ }^{1}$, Ping Cheng ${ }^{1}$, Wen-hua Li ${ }^{1}$, Yi-pin Lv ${ }^{1}$, Yong-sheng Teng $^{1}$, Gang \\ Guo $^{1}$, Ping Luo ${ }^{1}$, Weisan Chen ${ }^{3}$, Quan-ming Zou ${ }^{1}$, Yuan Zhuang ${ }^{1}$ \\ ${ }^{1}$ National Engineering Research Center of Immunological Products, Department of Microbiology and Biochemical Pharmacy, \\ College of Pharmacy, Third Military Medical University, Chongqing, PR China \\ ${ }^{2}$ Department of General Surgery and Center of Minimal Invasive Gastrointestinal Surgery, Southwest Hospital, Third Military \\ Medical University, Chongqing, PR China \\ ${ }^{3}$ La Trobe Institute for Molecular Science, La Trobe University, Bundoora, Victoria, Australia \\ Correspondence to: Yuan Zhuang, email: yuanzhuang1983@yahoo.com \\ Quan-ming Zou, email: qmzou@tmmu.edu.cn
}

Keywords: NKT-like cells, gastric cancer, functional impairment, tumor progression, immune escape

Received: December 08, 2015

Accepted: May 28, 2016

Published: July 08, 2016

\section{ABSTRACT}

$\mathrm{CD3}^{+} \mathrm{CD} 56^{+}$natural killer $\mathrm{T}(\mathrm{NKT})$-like cells are a group of $\mathrm{CD}^{+} \mathrm{T}$ cells sharing characteristics of $\mathrm{NK}$ and $\mathrm{T}$ cells and constitute a major component of host antitumor immune response in human cancer. However, the nature, function and clinical relevance of $\mathrm{CD}^{+}{ }^{+} \mathrm{CD} 56^{+}$NKT-like cells in human gastric cancer (GC) remain unclear. In this study, we showed that the frequencies of $\mathrm{CD3}+\mathrm{CD} 56^{+} \mathrm{NKT}$-like cells in GC tumors were significantly decreased and low levels of tumor-infiltrating $\mathrm{CD}^{+} \mathrm{CD}^{+} 6^{+}$ NKT-like cells were positively correlated with poor survival and disease progression. Most CD3 ${ }^{+}$CD56 ${ }^{+}$NKT-like cells in GC tumors were CD45RA-CD27+/- central/effectormemory cells with decreased activity and lower expression levels of CD69, NKG2D and DNAM-1 than those in non-tumor tissues. We further observed that tumor-infiltrating CD $3^{+}{ }^{+} D 56^{+}$NKT-like cells had impaired effector function as shown by decreased IFN-Y, TNF-a, granzyme B and Ki-67 expression. Moreover, in vitro studies showed that soluble factors released from GC tumors could induce the functional impairment of $\mathrm{CD}^{+} \mathrm{CD}^{+} 6^{+}$NKT-like cells. Collectively, our data indicate that decreased tumorinfiltrating $\mathrm{CD}^{+}{ }^{+} \mathrm{CD} 56^{+}$NKT-like cells with impaired effector function are associated with tumor progression and poor survival of GC patients, which may contribute to immune escape of GC.

\section{INTRODUCTION}

Gastric cancer (GC) is the fourth most common cancer worldwide often with poor prognosis [1]. The clinical relevance of $\mathrm{GC}$ has been recognized to be influenced by the cross-talk between tumors and host immune system, and a strong anti-tumor immune response in the tumor microenvironment is associated with a favorable clinical outcome [2]. However, although immune cell infiltration in GC is often observed, the antitumor immunity is commonly ineffective $[3,4]$.

$\mathrm{CD}^{+} \mathrm{CD}^{+} 6^{+}$NKT-like cells are a broad group of $\mathrm{CD}^{+} \mathrm{T}$ cells co-expressing $\mathrm{T}$-cell antigen receptor
(TCR) and NK-cell markers $[5,6]$. That is, $\mathrm{CD}^{+} \mathrm{CD}^{+} 6^{+}$ NKT-like cells share NK and T cell characteristics and possess both innate and acquired immune functions. Once TCR ligation, $\mathrm{CD}^{+} \mathrm{CD}^{2} 6^{+} \mathrm{NKT}$-like cells can be activated to secrete cytotoxic enzymes and cytokines to kill target cells [7]. On the other hand, $\mathrm{CD}^{+} \mathrm{CD} 56^{+}$ NKT-like cells are also able to mediate non-MHCrestricted lysis and cytokine production in the absence of TCR activation. Therefore, $\mathrm{CD}^{+}{ }^{+} \mathrm{CD} 56^{+}$NKT-like cells have been postulated to play an important role in anti-tumor and anti-virus immune response [8, 9]. In human cancers, including lung and colorectal cancers, high levels of $\mathrm{CD}^{+} \mathrm{CD}^{+} 6^{+}$NKT-like cells 
have been reported to be associated with improved patient's survival [10,11]. However, studies focusing on the functional activity of $\mathrm{CD} 3{ }^{+} \mathrm{CD} 56^{+} \mathrm{NKT}$-like cells showed that the cytotoxicity and cytokine production of these cells are impaired in haematological malignancies and other solid tumors, such as chronic lymphocytic leukemia and ovarian cancer [11, 12]. Interestingly, in acute leukemia, although higher numbers of $\mathrm{CD}^{+}{ }^{+} \mathrm{CD} 56^{+}$NKT-like cells were observed in the peripheral blood, their functions were significantly impaired [13]. Taken together, these data suggest that the anti-tumor activity of $\mathrm{CD} 3{ }^{+} \mathrm{CD} 56^{+}$NKT-like cells is likely altered in the tumor microenvironment. To our knowledge, the nature, function and clinical relevance of $\mathrm{CD}^{+}{ }^{+} \mathrm{CD} 56^{+}$NKT-like cells in $\mathrm{GC}$ patients remain largely unexplored.

In the present study, we firstly aim to examine the levels and functional activity of $\mathrm{CD} 3^{+} \mathrm{CD} 56^{+}$NKT-like cells in tumor and non-tumor tissues of GC patients, and then analyze the possible associations between these cells and clinical features of GC. We show that decreased levels of tumor-infiltrating $\mathrm{CD}^{+}{ }^{+} \mathrm{CD} 56^{+}$NKT-like cells with functional impairment correlated with tumor progression and poor overall survival of GC patients. Restoring their effector function should benefit antitumor immunity to GC.

\section{RESULTS}

\section{Frequencies and clinical associations of $\mathrm{CD3}^{+} \mathrm{CD56}^{+}{ }^{+} \mathrm{NKT}$-like cells in tumors of GC patients}

Using flow cytometry, we first analyzed the presence of $\mathrm{CD}^{+}{ }^{+} \mathrm{CD} 56^{+}$NKT-like cells in the peripheral blood of GC patients and healthy individuals. Figure 1A shows the gating strategy. We found that there was no difference in the frequencies of circulating $\mathrm{CD} 3{ }^{+} \mathrm{CD} 56^{+}$ NKT-like cells between healthy individuals and GC patients (Figure 1B, $5.17 \%, 0.37 \%-23.01 \%$ vs. $5.55 \%$, $1.22 \%-12.04 \%, P>0.05)$. Next we evaluated $\mathrm{CD}^{+}{ }^{+} \mathrm{CD} 56^{+}$ NKT-like cell frequencies in non-tumor and tumor tissues of GC patients. As shown in Figure 1C and 1D, the frequencies of $\mathrm{CD}^{+}{ }^{+} \mathrm{CD} 56^{+}$NKT-like cells in tumors were significantly lower than those in non-tumor tissues (4.44\%, $0.52 \%-18.10 \%$ vs. $7.20 \%, 0.23 \%-26.50 \%$, $P<0.01)$. Furthermore, low $\mathrm{CD}^{+}{ }^{+} \mathrm{CD} 56^{+}$NKT-like cell frequencies were shown to be positively correlated with patients' poorer overall survival according to the median value of tumor-infiltrating $\mathrm{CD}^{+} \mathrm{CD} 56^{+}$NKTlike cell frequencies (Figure 1E). In addition, low levels of tumor-infiltrating $\mathrm{CD}^{+}{ }^{+} \mathrm{CD} 56^{+}$NKT-like cells were also positively correlated with advanced clinical features,
A
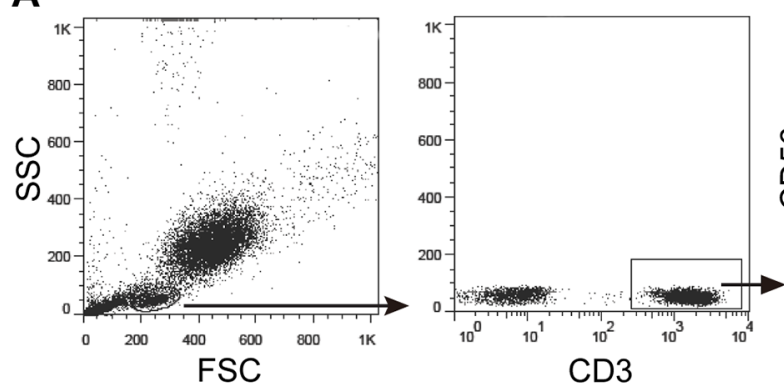

C
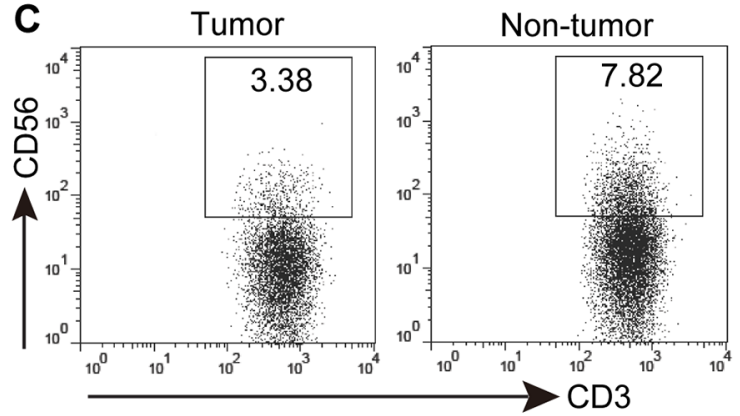

D

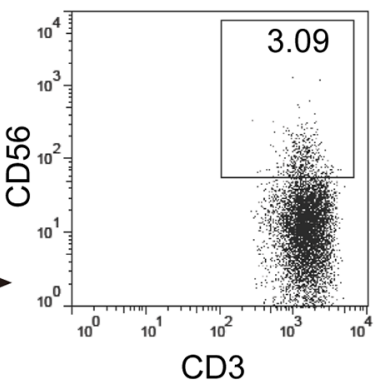

B

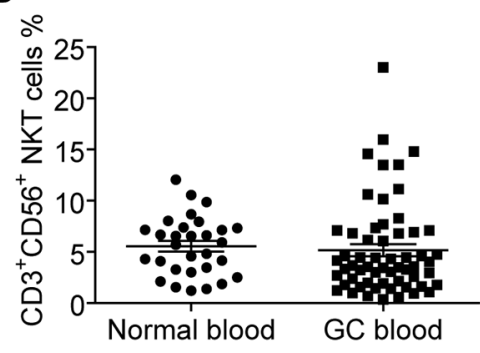

E
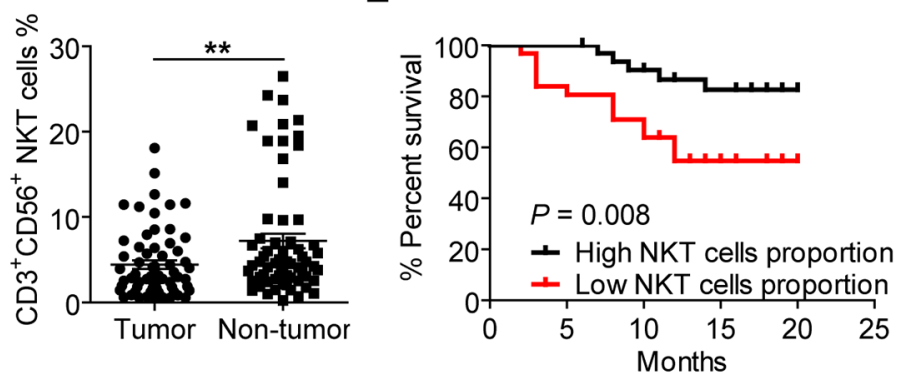

Figure 1: The prevalence of CD3+CD56+ NKT-like cells in peripheral blood, non-tumor and tumor tissues of GC patients. A. A representative flow cytometry analysis of $\mathrm{CD} 3{ }^{+} \mathrm{CD} 56^{+}$NKT-like cells in whole peripheral blood of GC patients after gating on $\mathrm{CD}^{+} \mathrm{T}$ cells. B. The frequencies of $\mathrm{CD} 3^{+} \mathrm{CD} 56^{+}$NKT-like cells in peripheral blood of 30 normal controls and $63 \mathrm{GC}$ patients. C. The representative dot plot of $\mathrm{CD}^{+}{ }^{+} \mathrm{CD} 56^{+} \mathrm{NKT}$-like cells after gating on $\mathrm{CD} 3^{+} \mathrm{T}$ cells in non-tumor and tumor tissues of the same patient. $\mathbf{D}$. The frequencies of $\mathrm{CD}^{+} \mathrm{CD} 56^{+} \mathrm{NKT}$-like cells in $\mathrm{CD}^{+} \mathrm{T}$ cells from non-tumor and tumor tissues of 63 patients. E. Kaplan-Meier plots for patients' overall survival by the median of tumor-infiltrating CD ${ }^{+} \mathrm{CD} 56^{+} \mathrm{NKT}$-like cells frequency $(2.99 \%)$. Statistical analysis in (B) and (D) was separately shown by unpaired and paired Student's $t$ test. Data were the mean $\pm \mathrm{SEM} ; * * \mathrm{P}<0.01$. 
including tumor size, tumor invasion, distant metastasis and tumor-node-metastasis (TNM) stages (Supplementary Figure S1). Thus, these data suggested that decreased tumor-infiltrating $\mathrm{CD}^{+} \mathrm{CD}^{+} 6^{+}$NKT-like cells are associated with tumor progression and GC patients' poorer overall survival.

\section{Phenotypic features of $\mathrm{CD3}^{+} \mathrm{CD56}^{+} \mathrm{NKT}$-like cells at tumor site}

Next we studied the phenotypic features of $\mathrm{CD}^{+} \mathrm{CD}^{+} 6^{+}$NKT-like cells at tumor site. As shown in Figure 2, we observed that the large majority of $\mathrm{CD}^{+} \mathrm{CD}^{+} 6^{+}$NKT-like cells in tumor tissues belonged to the $\mathrm{CD}^{+}$subset and were nearly devoid of $\gamma \delta \mathrm{TCR}^{+}$ cells and invariant $\mathrm{V} \alpha 24^{+} \mathrm{NKT}$ cells. In addition, tumorinfiltrating $\mathrm{CD}^{+} \mathrm{CD}^{+} 6^{+} \mathrm{NKT}$-like cells express low levels of CD45RA but intermediate level of CD27, suggesting that these cells were CD45RA-CD27 ${ }^{+/}$central/effectormemory cells (Supplementary Figure S2). Furthermore, we found that a higher level of CD69 on tumor-infiltrating $\mathrm{CD}^{+}{ }^{+} \mathrm{CD} 56^{+}$NKT-like cells than those on circulating $\mathrm{CD}^{+} \mathrm{CD}^{+} 6^{+}$NKT-like cells. However, compared with non-tumor tissues, the level of CD69 expression on $\mathrm{CD}^{+} \mathrm{CD}^{+} 6^{+} \mathrm{NKT}$-like cells in tumor tissues was significantly decreased (Supplementary Figure S3). We also observed that $\mathrm{CD}^{+} \mathrm{CD} 56^{+} \mathrm{NKT}$-like cells in tumors expressed lower level of inflammatory tissue homing markers CXCR3 and CCR5 than those in the peripheral blood. $\mathrm{CD}^{+}{ }^{+} \mathrm{CD} 56^{+}$NKT-like cells share similar surface receptor expression with $\mathrm{NK}$ cells. Therefore, the expression of NK-cell-associated activating and inhibitory receptors on $\mathrm{CD}^{+}{ }^{+} \mathrm{CD} 56^{+} \mathrm{NKT}$-like cells were determined. As shown in Figure 3, there were no differences for the expression of activating receptors including CD16, NKp30, NKp44, NKp46, CD38, CD94 and inhibitory receptors including NKG2A, TIGIT, PD-1, Tim-3, LAG$3, \mathrm{CD} 158 \mathrm{a} / \mathrm{h}, \mathrm{CD} 158 \mathrm{~b}$ on these cells in non-tumor and tumor tissues. However, the expression levels of activating receptors NKG2D and DNAM-1 on tumor-infiltrating $\mathrm{CD}^{+}{ }^{+} \mathrm{CD} 56^{+} \mathrm{NKT}$-like cells were significantly lower than those on non-tumor-infiltrating these cells (Figure 3 and S4). Based on the above observations, we concluded that $\mathrm{CD}^{+}{ }^{+} \mathrm{CD} 56^{+} \mathrm{NKT}$-like cells at tumor sites in GC patients have an overall central/effector-memory phenotype with decreased activation.
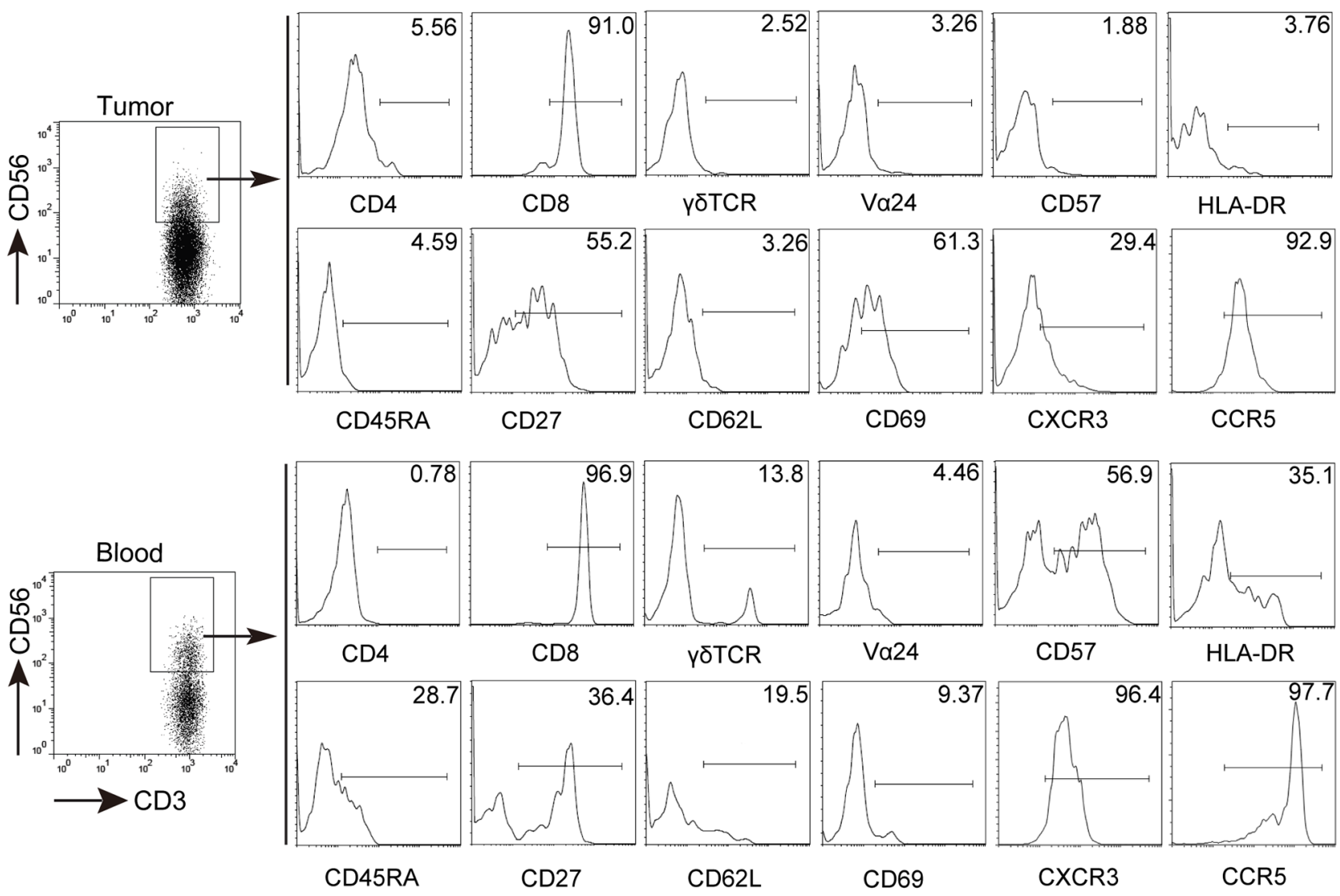

Figure 2: Phenotypic characteristics of CD3+CD56+ NKT-like cells in GC patients. Freshly isolated cells from tumor tissues and peripheral blood were stained with anti-CD3, anti-CD56, anti-CD4, anti-CD8, anti- $\gamma \delta$ TCR, anti-V $\alpha$ 24, anti-CD57, anti-HLA-DR, anti-CD45RA, anti-CD27, anti-CD62L, anti-CD69, CXCR3 and CCR5 antibodies. Cells were gated on CD3 ${ }^{+} \mathrm{CD} 56^{+} \mathrm{NKT}$-like cells and the expression of CD4, CD8, $\gamma \delta$ TCR, V $\alpha$ 24, CD57, HLA-DR, CD45RA, CD27, CD62L, CD69, CXCR3, CCR5 was analyzed. 


\section{Effector function of GC-infiltrating $\mathrm{CD3}^{+} \mathrm{CD56}^{+}$NKT-like cells}

To investigate the effector function of $\mathrm{CD}^{+} \mathrm{CD}^{+} 6^{+}$ NKT-like cells, polyclonal stimulation was carried out for detecting intracellular cytokines production. As shown in Figure 4, the majority of non-tumorinfiltrating $\mathrm{CD} 3{ }^{+} \mathrm{CD} 56^{+}$NKT-like cells produced IFN- $\gamma$ and TNF- $\alpha$, but in tumors, we observed that significantly lower frequencies of IFN- $\gamma$ and TNF- $\alpha$-producing $\mathrm{CD}^{+}{ }^{+} \mathrm{CD}^{2} 6^{+}$NKT-like cells than those in non-tumor tissues. In addition, the frequency of granzyme $\mathrm{B}$ in tumor-infiltrating $\mathrm{CD}^{+} \mathrm{CD} 56^{+}$NKT-like cells was also lower than that of the counterparts in non-tumor tissues, suggesting that the cytokine and cytotoxic molecule production of tumor-infiltrating $\mathrm{CD}^{+} \mathrm{CD}^{+} 6^{+}$NKT-like cells were decreased. We further analyzed the proliferation status of tumor-infiltrating $\mathrm{CD}^{+} \mathrm{CD} 56^{+}$NKT-like cells. Although relatively low levels of proliferation-associated marker Ki-67 were detected in both non-tumor and tumorinfiltrating $\mathrm{CD}^{+}{ }^{+} \mathrm{CD} 56^{+}$NKT-like cell populations, Ki-67 level in tumor-infiltrating $\mathrm{CD}^{+} \mathrm{CD}^{+} 6^{+}$NKT-like cells were significantly decreased. Taken together, these results indicated that while infiltrated in the tumors, the effector function of $\mathrm{CD}^{+} \mathrm{CD} 56^{+}$NKT-like cells were likely impaired.

\section{Effect of tumor microenvironment on $\mathrm{CD3}^{+} \mathrm{CD56}^{+} \mathrm{NKT}$-like cells' effector function}

To address whether soluble factors from GC microenvironment could influence the effector function of $\mathrm{CD}^{+}{ }^{+} \mathrm{CD} 56^{+}$NKT-like cells, tumor tissue culture supernatant (TTCS) and non-tumor tissue culture supernatant (NTCS) were used to culture PBMCs from healthy individuals for 48 hours. As shown in Figure 5, the expression of IFN- $\gamma$, TNF- $\alpha$, granzyme B and Ki67 in TTCS-treated $\mathrm{CD}^{+}{ }^{+} \mathrm{CD} 56^{+}$NKT-like cells were significantly lower that those in the NTCS-treated group, suggesting that the effector function of $\mathrm{CD}^{+}{ }^{+} \mathrm{CD} 56^{+} \mathrm{NKT}-$ like cells is suppressed by soluble factor from TTCS. However, such functional impairment of $\mathrm{CD}^{+} \mathrm{CD} 56^{+}$ NKT-like cells was independent on TGF- $\beta 1$ as blocking TGF- $\beta 1$ signaling did not significantly attenuate TTCS-

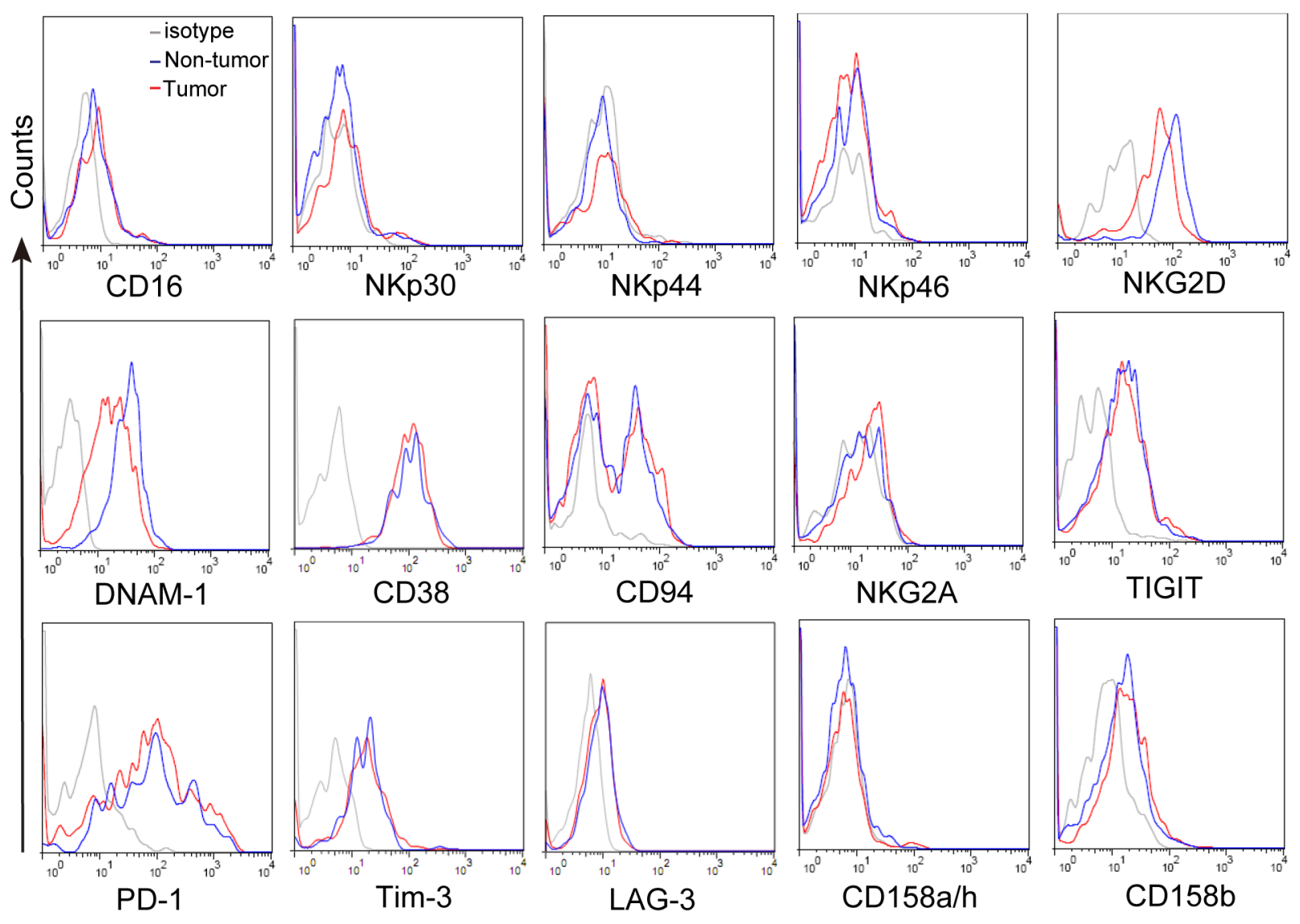

Figure 3: The expression of NK-cell-associated activating and inhibitory receptors on CD3+CD56+ NKT-like cells. Freshly isolated cells from tumor and non-tumor tissues were stained with anti-CD3, anti-CD56, anti-CD16, anti-NKp30, anti-NKp44, anti- NKp46, anti-NKG2D, anti-DNAM-1, anti-CD38, anti-CD94, anti-NKG2A, anti-TIGIT, anti-PD-1, anti-Tim-3, anti-LAG-3, anti$\mathrm{CD} 158 \mathrm{a} / \mathrm{h}$ and anti-CD158b antibodies. Cells were gated on CD3 ${ }^{+} \mathrm{CD} 56^{+}$NKT-like cells and the expression of CD16, NKp30, NKp44, NKp46, NKG2D, DNAM-1, CD38, CD94, and NKG2A, TIGIT, PD-1, Tim-3, LAG-3, CD158a/h, CD158b was analyzed. 
mediated suppression of IFN- $\gamma$, TNF- $\alpha$, granzyme B and $\mathrm{Ki}-67$ in $\mathrm{CD}^{+} \mathrm{CD}^{+} 6^{+} \mathrm{NKT}-1$ ike cells. Above all, these results suggested that soluble factor(s) from GC tumors could induce the functional impairment of $\mathrm{CD}^{+} \mathrm{CD}^{+} 6^{+}$ NKT-like cells.

\section{DISCUSSION}

Deciphering the role of host immune system in the tumor microenvironment is crucial for understanding how they affect the development and course of human tumors $[14,15]$. Despite recent success in delineating the function and clinical relevance of tumor-infiltrating lymphocytes (TIL) including conventional $\mathrm{CD}^{+} \mathrm{T}$ cells and CD3 $\mathrm{CD}^{+} 6^{+} \mathrm{NK}$ cells in human GC $[16,17]$, the relationship between $\mathrm{CD}^{+} \mathrm{CD}^{+} 6^{+}$NKT-like cells, another subset of TIL, and GC progression is completely unknown. Here, our study showed for the first time that within $\mathrm{GC}$, the frequencies of $\mathrm{CD}^{+} \mathrm{CD}^{2} 6^{+} \mathrm{NKT}$-like cells were significantly decreased, and low levels of $\mathrm{CD}^{+} \mathrm{CD}^{+} 6^{+}$ NKT-like cells were positively correlated with patients' poor overall survival, suggesting that the frequencies of tumor-infiltrating $\mathrm{CD}^{+} \mathrm{CD}^{+} 6^{+}$NKT-like cells may be a good marker of GC patients' prognosis. Furthermore, we observed a strong negative association between their levels and advanced clinical features, including tumor size, tumor invasion, distant metastasis and TNM stages, indicating that lower level of $\mathrm{CD}^{+} \mathrm{CD}^{+} 6^{+} \mathrm{NKT}$-like cells in tumors may have contributed to $\mathrm{GC}$ progression.

$\mathrm{CD}^{+} \mathrm{CD}^{+} 6^{+}$NKT-like cells have been reported to be highly heterogeneous, for they contain $\mathrm{CD} 4^{+}, \mathrm{CD}^{+}$, $\mathrm{CD}^{-\mathrm{CD}} 8^{-}$and even $\gamma \delta \mathrm{TCR}^{+}$cells and invariant $\mathrm{V} \alpha 24^{+}$ NKT cells [18]. However, in our study, we showed that the majority of these cells in tumor tissues expressed CD8 molecule but not $\gamma \delta$ or $\mathrm{V} \alpha 24 \mathrm{NKT}$ cell TCR, indicating that most of the GC-infiltrating $\mathrm{CD}^{+} \mathrm{CD}^{2} 6^{+} \mathrm{NKT}$-like cells were $\mathrm{CD}^{+} \mathrm{T}$ cells, not $\gamma \delta \mathrm{T}$ cells or invariant $\mathrm{V} \alpha 24^{+} \mathrm{NKT}$ cells. CXCR3 and CCR5 are inflammatory tissue homing molecules that play a crucial role in $\mathrm{CD}^{+} \mathrm{T}$ cell migration [19]. However, their levels on $\mathrm{GC}$-infiltrating $\mathrm{CD}^{+} \mathrm{CD}^{+} 6^{+}$ NKT-like cells were lower than those in the peripheral blood, implying that a significant drop of CXCR3 and CCR5 expression on $\mathrm{CD}^{+}{ }^{+} \mathrm{CD} 56^{+}$NKT-like cells may be accompanied by the infiltration of these cells in tumors. The cell differentiation and activation status is important for their effector function [20, 21]. The combination CD45RA and CD27 expression can separate human T cells into four subsets: $\mathrm{CD} 45 \mathrm{RA}^{+} \mathrm{CD} 27^{+}$naïve, $\mathrm{CD}^{4} \mathrm{RA}{ }^{-}$

A
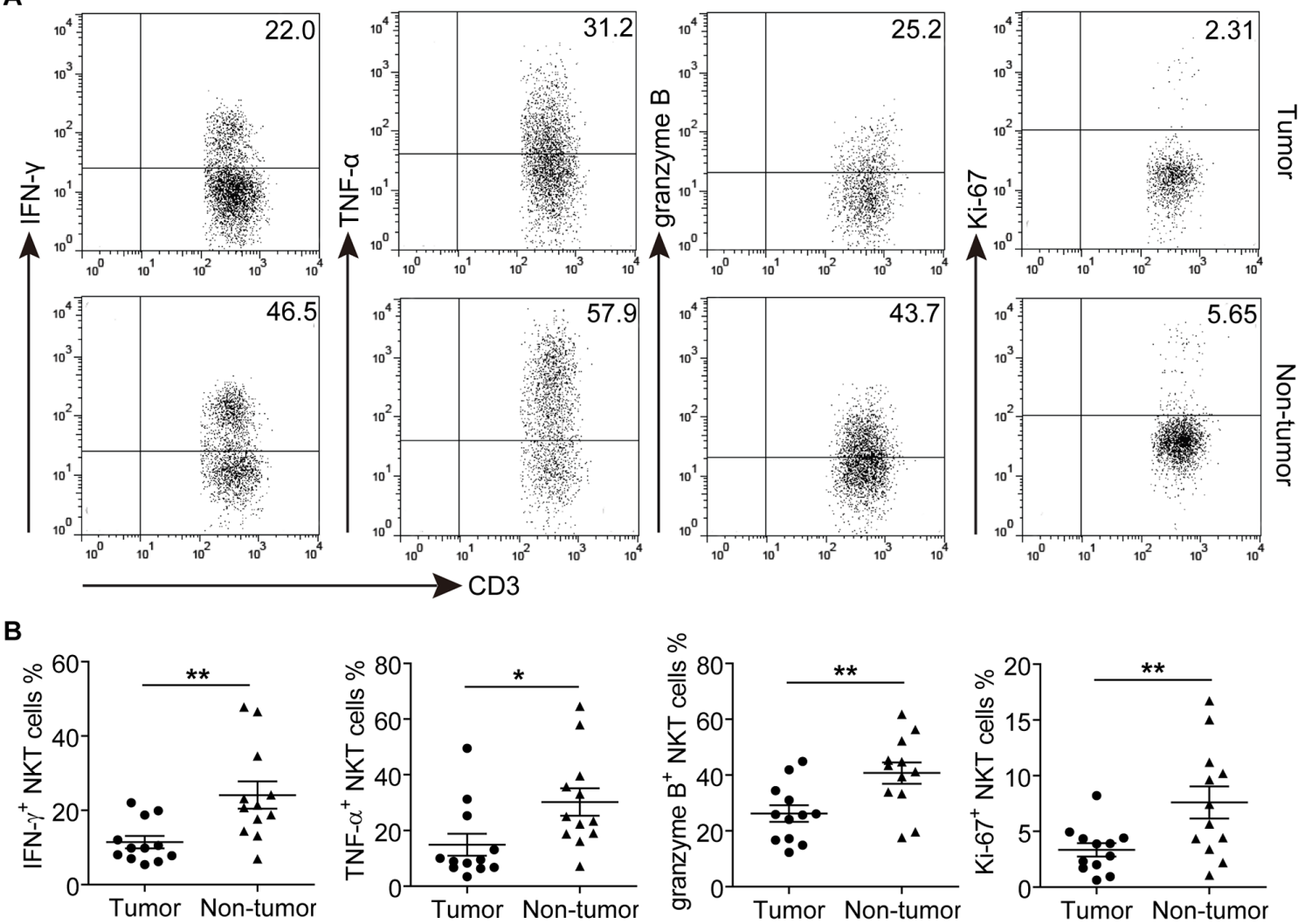

Figure 4: The effector functions of tumor and non-tumor-infiltrating CD3+CD56+ NKT-like cells in GC patients. A-B. Representative dot plots (A) and Statistical analyses (B) of IFN- $\gamma$, TNF- $\alpha$, granzyme B and Ki-67 in CD3 ${ }^{+}$CD56 ${ }^{+}$NKT-like cells from paired tumor and non-tumor tissues of GC patient. Symbols represent individual values, and 12 GC patients analyzed individually. ${ }^{*} \mathrm{P}<0.05,{ }^{*} * \mathrm{P}<0.01$. 

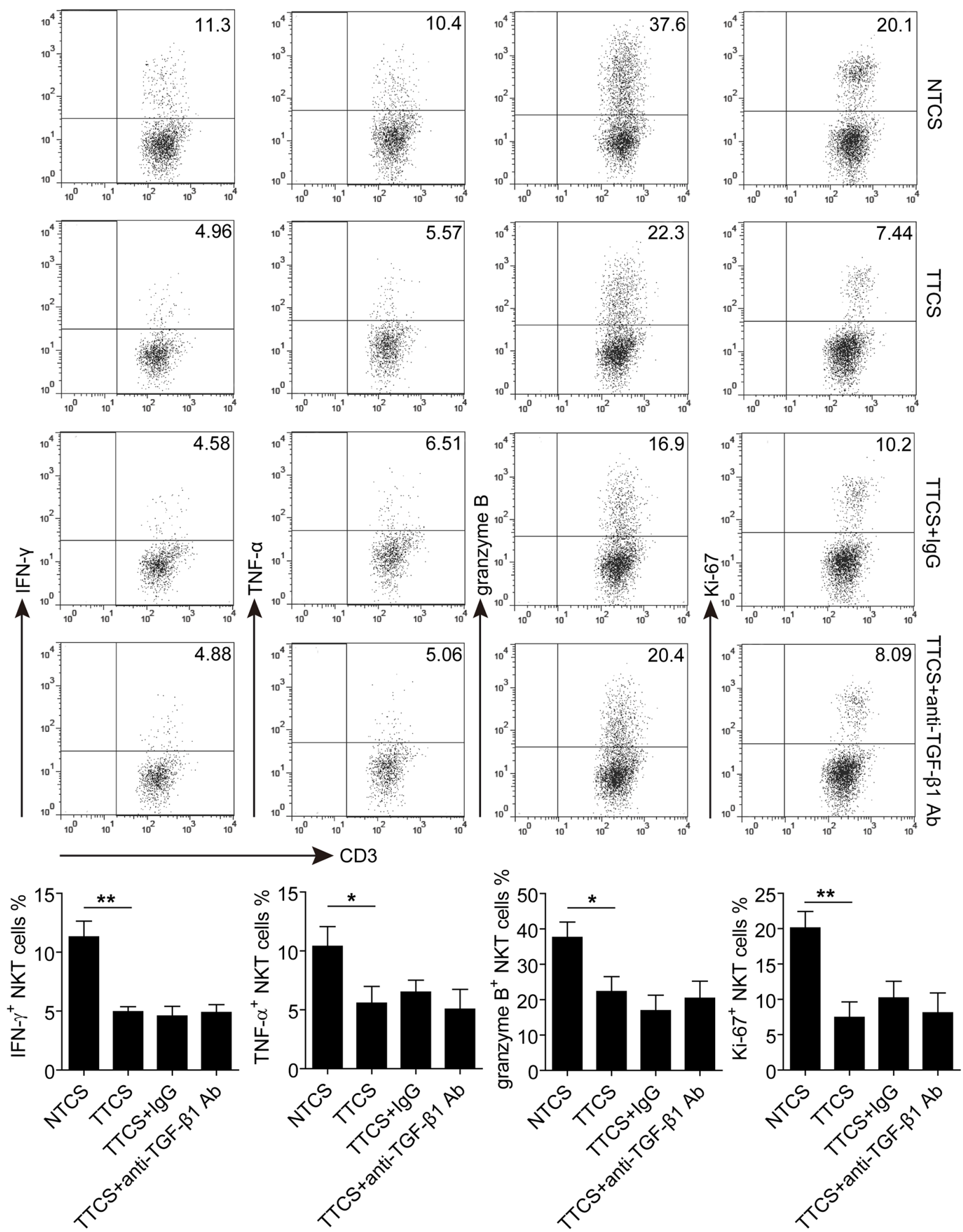

Figure 5: The functional impairment of CD3+CD56+ NKT-like cells induced by soluble factor(s) from tumor tissue culture supernatant. PBMCs from healthy individuals were cultured for 48 hours with $10 \%$ TTCS or NTCS in the presence of rhIL-2, anti-CD3 and anti-CD28 antibodies. Where indicated, $10 \mu \mathrm{g} / \mathrm{ml}$ anti-TGF- $\beta 1$ or isotype IgG antibody was added as described in Materials and Methods. The expression of IFN- $\gamma$, TNF- $\alpha$, granzyme B and Ki-67 in CD $3^{+} \mathrm{CD}^{2} 6^{+}$NKT-like cells were determined by flow cytometry. In total, PBMCs from three healthy individuals were used to culture with TTCS and NTCS from two GC patients. ${ }^{*} \mathrm{P}<0.05, * * \mathrm{P}<0.01$. Ab, antibody. 
$\mathrm{CD}_{27^{+}}$central-memory, CD45RA-CD27- effectormemory and $\mathrm{CD} 45 \mathrm{RA}^{+} \mathrm{CD} 27^{-}$terminally-differentiated $\mathrm{T}$ cells $[22,23]$. We observed that tumor-infiltrating $\mathrm{CD}^{+} \mathrm{CD}^{2} 6^{+}$NKT-like cells belonged to the CD45RA $\mathrm{CD} 27^{+}$and $\mathrm{CD} 45 \mathrm{RA}^{-} \mathrm{CD} 27^{-}$subset, indicating that these $\mathrm{CD}^{+} \mathrm{CD}^{+} 6^{+}$NKT-like cells were central/effector-memory cells and matured in tumors. However, the activation marker CD69 expressing on $\mathrm{CD}^{+}{ }^{+} \mathrm{CD} 56^{+}$NKT-like cells in tumors were significantly fewer than those in nontumor tissues. Furthermore, NK-cell activating receptors NKG2D and DNAM-1 expression were also decreased on tumor-infiltrating $\mathrm{CD}^{+} \mathrm{CD}^{+} 6^{+}$NKT-like cells. Therefore, although $\mathrm{CD}^{+}{ }^{+} \mathrm{CD} 56^{+}$NKT-like cells in $\mathrm{GC}$ tumors were shown to have a matured phenotype, their activities might be suppressed. $\mathrm{CD}^{+} \mathrm{CD} 56^{+}$NKT-like cells carry out their anti-tumor function by producing cytokines and/or releasing cytotoxic molecules [24]. However, our study showed that $\mathrm{CD}^{+} \mathrm{CD}^{+} 6^{+}$NKT-like cells in GC tumors displayed impaired effector function when stimulated, such as lower IFN- $\gamma$ and TNF- $\alpha$ production than those in non-tumor tissues. Moreover, the expression of granzyme B and proliferation-associated marker Ki-67 in tumor-infiltrating $\mathrm{CD}^{+}{ }^{+} \mathrm{CD} 56^{+}$NKT-like cells were also decreased. Therefore, decreased cytokines production, cytotoxic potential and proliferation capacity of $\mathrm{CD}^{+} \mathrm{CD}^{+} 6^{+}$NKT-like cells will likely lead to worsening clinical course.

It is important to elucidate the functional regulation of $\mathrm{CD}^{+} \mathrm{CD}^{2} 6^{+}$NKT-like cells in GC. Coinhibitory molecules such as PD-1, Tim-3, LAG-3 and TIGIT have been widely reported to inhibit T-cell and NK-cell function [25-27]. However, the expression of these molecules were not altered on tumor-infiltrating $\mathrm{CD}^{+}{ }^{+} \mathrm{CD} 56^{+}$NKT-like cells from GC patients. Instead, soluble inhibitory factors released by tumor cells or tumor-infiltrating immune cells might mediate such functional impairment of $\mathrm{CD} 3{ }^{+} \mathrm{CD} 56^{+}$NKT-like cells, for we observed that tumor tissue culture supernatant from GC patients impaired the effector function of $\mathrm{CD}^{+}{ }^{+} \mathrm{CD} 56^{+}$NKT-like cells. Other studies have shown that tumor microenvironment can secrete inhibitory factor TGF- $\beta 1$ to prevent effective anti-tumor immune response and blocking TGF- $\beta$ signaling has emerged as a potential therapeutic approach for tumor treatment $[28,29]$. However, our study showed that the functional impairment of $\mathrm{CD}^{+} \mathrm{CD} 56^{+}$NKT-like cells was not rescued following TGF- $\beta 1$ blockade, suggesting other soluble factor's involvement from tumor microenvironment rather than TGF- $\beta 1$.

In conclusion, our study demonstrated that decreased tumor-infiltrating $\mathrm{CD}^{+}{ }^{+} \mathrm{CD} 56^{+}$NKT-like cells and their impaired functionality lead to immune suppression and GC progression, and unveiled that GC microenvironment may form an inhibitory milieu to impair the function of $\mathrm{CD}^{+} \mathrm{CD}^{2} 6^{+}$NKT-like cells. These findings will be helpful for developing novel immune-based GC therapies.

\section{MATERIALS AND METHODS}

\section{Patients and tissue samples}

Fresh peripheral blood, normal autologous gastric tissues (non-tumor, at least $5-\mathrm{cm}$ distance from the tumor site) and tumor tissues were obtained from 63 nevertreated GC patients during surgery at the Southwest Hospital of the Third Military Medical University. The clinical stages of tumors were determined according to the TNM classification system of International Union against Cancer (Edition 7). Normal blood was collected from 30 healthy individuals as the control group. The study was approved by the Ethics Committee of the Third Military Medical University, and written informed consent was obtained from each subject. The clinical characteristics of GC Patients were present in Supplementary Table S1.

\section{Cell isolation}

Fresh non-tumor and tumor tissues were used for obtaining cell suspensions as previously described [30]. Briefly, paired non-tumor and tumor tissues were cut into small pieces and collected in RPMI 1640 containing $1 \mathrm{mg} / \mathrm{ml}$ collagenase IV (Sigma-Aldrich, St.Louis, MO) and $10 \mathrm{mg} / \mathrm{ml}$ Dnase I (Roche, Basel, Switzerland), then mechanically dissociated by using the gentle MACS Dissociator (Miltenyi Biotec, Auburn, CA). Dissociated cell suspensions were further incubated 1 hour at $37^{\circ} \mathrm{C}$ under continuous rotation and filtered through $70 \mu \mathrm{m}$ cell strainers to obtain cell suspensions. The cell suspensions were then used for flow cytometry analysis.

\section{Flow cytometric analysis}

Cells suspensions were stained with appropriate surface antibodies, and then fixed, permeabilized for 20 min using Cytofix/Cytoperm reagent (BD Biosciences), and subsequently stained with antibodies to intracellular molecules granzyme B and Ki-67. For intracellular cytokine staining of IFN- $\gamma$ and TNF- $\alpha$, the cells were stimulated for 4 hours with phorbol myristate acetate (PMA, $50 \mathrm{ng} / \mathrm{ml}$ ) and ionomycin $(1 \mu \mathrm{g} / \mathrm{ml})$ in the presence of Golgistop before staining. The fluorochrome-labeled antibodies are listed in Supplementary Table S2.

\section{Preparation of tissue culture supernatant}

Tumor tissue culture supernatant (TTCS) or nontumor tissue culture supernatant (NTCS) was prepared as previously described [4].

\section{Culturing and stimulation of PBMCs}

Peripheral blood mononuclear cells (PBMCs) from healthy individuals were isolated by Ficoll density gradient 
centrifugation. PBMCs were seeded in the 96-well round bottom plates at $4 \times 10^{5}$ cells/well in RPMI 1640 containing 10\% fetal calf serum (Gibco, Bionova, Uruguay). $20 \mathrm{U} /$ $\mathrm{ml}$ recombinant human IL-2 (rhIL-2) was supplemented to each well pre-coated with anti-CD3 $(2 \mu \mathrm{g} / \mathrm{ml})$ and anti-CD28 (1 $\mu \mathrm{g} / \mathrm{ml})$ antibodies (Biolegend, San Diego, CA). In some experiments, $10 \%$ TTCS or NTCS was also added in the well. Where indicated, anti-TGF- $\beta 1$ neutralizing antibody $(10 \mu \mathrm{g} / \mathrm{ml}, \mathrm{Abcam})$ or isotype control IgG antibody was added in the $10 \%$ TTCS-treated wells. After 48 hours, plated cells were collected for intracellular granzyme $\mathrm{B}$ and $\mathrm{Ki}-67$ expression in $\mathrm{CD}^{+} \mathrm{CD}^{+} 6^{+} \mathrm{NKT}-$ like cells of PBMCs. For intracellular cytokine staining of IFN- $\gamma$ and TNF- $\alpha$, the cells were stimulated at the last 4 hours with PMA $(50 \mathrm{ng} / \mathrm{ml})$ and ionomycin $(1 \mu \mathrm{g} / \mathrm{ml})$ in the presence of Golgistop before staining.

\section{Statistical analysis}

All results are summarized as mean \pm standard error of the mean (SEM), and statistical analysis was performed with the Prism 5.0 Software. Differences between groups were evaluated by two-tailed Student's $t$ test. Cumulative survival time was measured in months and calculated by the Kaplan-Meier method. $P<0.05$ was considered statistically significant.

\section{CONFLICTS OF INTEREST}

No potential conflicts of interest were disclosed.

\section{FUNDING}

This work was supported by grants of the National Natural Science Foundation of China (NSFC, No. 81502457 and No. 81402355).

\section{REFERENCES}

1. Torre LA, Bray F, Siegel RL, Ferlay J, Lortet-Tieulent J, Jemal A. Global cancer statistics, 2012. CA Cancer J Clin. 2015; 65: 87-108.

2. Lee HE, Chae SW, Lee YJ, Kim MA, Lee HS, Lee BL, Kim WH. Prognostic implications of type and density of tumour-infiltrating lymphocytes in gastric cancer. $\mathrm{Br} \mathrm{J}$ Cancer. 2008; 99: 1704-11.

3. Apetoh L, Smyth MJ, Drake CG, Abastado JP, Apte RN, Ayyoub M, Blay JY, Bonneville M, Butterfield LH, Caignard A, Castelli C, Cavallo F, Celis E, et al. Consensus nomenclature for $\mathrm{CD} 8+\mathrm{T}$ cell phenotypes in cancer. Oncoimmunology. 2015; 4: e998538.

4. Zhuang Y, Peng LS, Zhao YL, Shi Y, Mao XH, Chen W, Pang KC, Liu XF, Liu T, Zhang JY, Zeng H, Liu KY, Guo G, et al. CD8(+) T cells that produce interleukin-17 regulate myeloid-derived suppressor cells and are associated with survival time of patients with gastric cancer. Gastroenterology. 2012; 143: 951-62.e8.

5. Godfrey DI, MacDonald HR, Kronenberg M, Smyth MJ, Van Kaer L. NKT cells: what's in a name? Nat Rev Immunol. 2004; 4: 231-7.

6. Kronenberg M. Toward an understanding of NKT cell biology: progress and paradoxes. Annu Rev Immunol. 2005; 23:877-900.

7. Golden-Mason L, Castelblanco N, O'Farrelly C, Rosen HR. Phenotypic and functional changes of cytotoxic CD56pos natural $\mathrm{T}$ cells determine outcome of acute hepatitis $\mathrm{C}$ virus infection. J Virol. 2007; 81: 9292-8.

8. Lu PH, Negrin RS. A novel population of expanded human $\mathrm{CD} 3+\mathrm{CD} 56+$ cells derived from $\mathrm{T}$ cells with potent in vivo antitumor activity in mice with severe combined immunodeficiency. J Immunol. 1994; 153: 1687-96.

9. Kokordelis P1, Krämer B, Boesecke C, Voigt E, Ingiliz P, Glässner A, Wolter F, Srassburg CP, Spengler U, Rockstroh JK, Nattermann J. CD3(+)CD56(+) Natural Killer-Like T Cells Display Anti-HCV Activity but Are Functionally Impaired in HIV(+) Patients With Acute Hepatitis C. J Acquir Immune Defic Syndr. 2015; 70: 338-46.

10. Pan K, Wang QJ, Liu Q, Zheng HX, Li YQ, Weng DS, Li JJ, Huang LX, He J, Chen SP, Ke ML, Zeng YX, Xia JC. The phenotype of ex vivo generated cytokine-induced killer cells is associated with overall survival in patients with cancer. Tumour Biol. 2014; 35: 701-7.

11. Bojarska-Junak A, Hus I, Sieklucka M, Wasik-Szczepanek E, Mazurkiewicz T, Polak P, Dmoszynska A, Rolinski J. Natural killer-like T CD3+/CD16+CD56+ cells in chronic lymphocytic leukemia: intracellular cytokine expression and relationship with clinical outcome. Oncol Rep. 2010; 24: 803-10.

12. Wang $H$, Yang $D, X u ~ W$, Wang $Y$, Ruan Z, Zhao T, Han J, Wu Y. Tumor-derived soluble MICs impair CD3(+) CD56(+) NKT-like cell cytotoxicity in cancer patients. Immunol Lett. 2008; 120: 65-71.

13. Guo W, Xing C, Dong A, Lin X, Lin Y, Zhu B, He M, Yao R. Numbers and cytotoxicities of CD3+CD56+ T lymphocytes in peripheral blood of patients with acute myeloid leukemia and acute lymphocytic leukemia. Cancer Biol Ther. 2013; 14: 916-21.

14. Galon J, Angell HK, Bedognetti D, Marincola FM. The continuum of cancer immunosurveillance: prognostic, predictive, and mechanistic signatures. Immunity. 2013; 39: 11-26.

15. Pagès F, Galon J, Dieu-Nosjean MC, Tartour E, SautèsFridman C, Fridman WH. Immune infiltration in human tumors: a prognostic factor that should not be ignored. Oncogene. 2010; 29: 1093-102.

16. Liu K, Yang K, Wu B, Chen H, Chen X, Chen X, Jiang L, Ye F, He D, Lu Z, Xue L, Zhang W, Li Q, et al. TumorInfiltrating Immune Cells Are Associated With Prognosis of Gastric Cancer. Medicine (Baltimore). 2015; 94: e1631. 
17. Lee HE, Chae SW, Lee YJ, Kim MA, Lee HS, Lee BL, Kim $\mathrm{WH}$. prognostic implications of type and density of tumour infiltrating lymphocytes in gastric cancer. $\mathrm{Br} \mathrm{J}$ Cancer. 2008; 99: 1704-11.

18. Norris S, Doherty DG, Collins C, McEntee G, Traynor O, Hegarty JE, O'Farrelly C. Natural T cells in the human liver: cytotoxic lymphocytes with dual $\mathrm{T}$ cell and natural killer cell phenotype and function are phenotypically heterogenous and include Valpha24-JalphaQ and gammadelta T cell receptor bearing cells. Hum Immunol. 1999; 60: 20-31.

19. Zumwalt TJ, Arnold M, Goel A, Boland CR. Active secretion of CXCL10 and CCL5 from colorectal cancer microenvironments associates with GranzymeB+ CD8+ T-cell infiltration. Oncotarget. 2015; 6: 2981-91. doi: 10.18632/oncotarget.3205.

20. Di Mitri D1, Azevedo R, Henson SM, Libri V, Riddell NE, Macaulay R, Kipling D, Soares MV, Battistini L, Akbar AN. Reversible senescence in human CD4+CD45RA+CD27memory T cells. J Immunol. 2011; 187: 2093-100.

21. Vivier E, Raulet DH, Moretta A, Caligiuri MA, Zitvogel L, Lanier LL, Yokoyama WM, Ugolini S. Innate or adaptive immunity? The example of natural killer cells. Science. 2011; 331: 44-9.

22. Delobel P, Nugeyre MT, Cazabat M, Sandres-Sauné K, Pasquier C, Cuzin L, Marchou B, Massip P, Cheynier R, Barré-Sinoussi F, et al. Naïve T-Cell Depletion Related to Infection by X4 Human Immunodeficiency Virus Type 1 in Poor Immunological Responders to Highly Active Antiretroviral Therapy. J Virol. 2006; 80: 10229-36.

23. Jackson SE, Mason GM, Okecha G, Sissons JG, Wills MR. Diverse specificities, phenotypes, and antiviral activities of cytomegalovirus-specific CD8+ T cells. J Virol. 2014; 88: 10894-908.
24. Pievani A, Borleri G, Pende D, Moretta L, Rambaldi A, Golay J, Introna M. Dual-functional capability of CD3+CD56+ CIK cells, a T-cell subset that acquires NK function and retains TCR-mediated specific cytotoxicity. Blood. 2011; 118: 3301-10.

25. Topalian SL, Drake CG, Pardoll DM. Immune checkpoint blockade: a common denominator approach to cancer therapy. Cancer Cell. 2015; 27: 450-61.

26. Johnston RJ, Comps-Agrar L, Hackney J, Yu X, Huseni M, Yang Y, Park S, Javinal V, Chiu H, Irving B, Eaton DL, Grogan JL. The immunoreceptor TIGIT regulates antitumor and antiviral CD8(+) T cell effector function. Cancer Cell. 2014; 26: 923-37.

27. Benson DM Jr, Bakan CE, Mishra A, Hofmeister CC, Efebera Y, Becknell B, Baiocchi RA, Zhang J, Yu J, Smith MK, Greenfield CN, Porcu P, Devine SM, et al. The PD-1/ PD-L1 axis modulates the natural killer cell versus multiple myeloma effect: a therapeutic target for CT-011, a novel monoclonal anti-PD-1 antibody. Blood. 2010; 116: 2286-94.

28. Thomas DA, Massagué J. TGF-beta directly targets cytotoxic $\mathrm{T}$ cell functions during tumor evasion of immune surveillance. Cancer Cell. 2005; 8: 369-80.

29. Wrzesinski SH, Wan YY, Flavell RA. Transforming growth factor-beta and the immune response: implications for anticancer therapy. Clin Cancer Res. 2007; 13: 5262-70.

30. Peng LS, Zhuang Y, Shi Y, Zhao YL, Wang TT, Chen N, Cheng P, Liu T, Liu XF, Zhang JY, Zuo QF, Mao XH, Guo $\mathrm{G}$, et al. Increased tumor-infiltrating CD8(+)Foxp3 (+) T lymphocytes are associated with tumor progression in human gastric cancer. Cancer Immunol Immunother. 2012; 61: 2183-92. 